\title{
Fossil thrips of the family Uzelothripidae suggest 53 million years of morphological and ecological stability
}

\author{
Patricia Nel, Alexander R. Schmidt, Claus Bässler, and André Nel \\ Acta Palaeontologica Polonica 58 (3), 2012: 609-614 doi: http://dx.doi.org/10.4202/app.2011.0016
}

The new fossil thrips Uzelothrips eocenicus P. Nel and A. Nel sp. nov. (Thysanoptera:

Uzelothripidae) is described from two lowermost Eocene amber-preserved specimens (one macropterous and one apterous). The family Uzelothripidae is only known so far from a single extant species, Uzelothrips scabrosus. The fossils differ from the extant species only by the antennal segments III and IV, which appear distinctly separated instead of being fused as in the in the extant U. scabrosus. Dark-coloured hyphae and conidia of the Dothideomycetes (Ascomycota) which are likely to belong to the sooty moulds (Capnodiales) are attached to the apterous fossil specimen. We consider this arthropod-fungus association not to be accidental since these fungi are also found in extant specimens of these uzelothripids, suggesting very specific long-term interactions and strong habitat specificity.

Key words: Arthropoda, Thysanoptera, Uzelothripidae, fossil fungi, Ascomycota, Capnodiales, sooty moulds, amber, Eocene, France.

Patricia Nel [pnel@mnhn.fr], CNRS UMR 7205, MNHN, CP 50, Entomologie, 45 Rue Buffon, F-75005 Paris, France, and AgroParisTech, 16 rue Claude Bernard, F-75231 Paris Cedex 05, France; Alexander R. Schmidt [alexander.schmidt@geo.uni-goettingen.de

], Georg-August-Universität Göttingen, Courant Research Centre Geobiology, Goldschmidtstr. 3, 37077 Göttingen, Germany; Claus

Bässler [claus.baessler@npv-bw.bayern.de], Nationalparkverwaltung Bayerischer Wald, Sachgebiet Forschung und Dokumentation, Freyunger Str. 2, 94481 Grafenau, Germany; André Nel [anel@mnhn.fr], CNRS UMR 7205, MNHN, CP 50, Entomologie, 45 Rue Buffon, F-75005 Paris, France. 
Attribution License (for details please see creativecommons.org), which permits unrestricted use, distribution, and reproduction in any medium, provided the original author and source are credited.

PoFif Full text $(310.9 \mathrm{kB})$ 